\title{
touching the soul? exploring an alternative outlook for philosophical work with children and young people
}

\author{
gert biesta ${ }^{1}$ \\ brunel university london, united kindom
}

\begin{abstract}
\end{abstract}
Philosophical work with children - which I take as an encompassing and slightly more descriptive phrase to cover a range of educational activities with children and young people in which philosophy plays a role - occupies a rather unique place in the contemporary curriculum and the modern school in many countries around the world. It not just provides a breath of fresh air, but also acts as a reminder that there is more to education than where policy makers and politicians keep wanting to push it, and also that education ought to be more than this. But the question I wish to ask is whether it is enough. In this paper, I I'll share some of my observations about my experiences with philosophical work with children and young people, not to pass any judgement on this. Perhaps the best way to 'read' my argument is to see it as the sharing of a question - a question relevant for all educational projects, programmes, endeavours and practices, and hence also relevant for philosophical work with children and young people. The question I raise is how particular educational practices, settings and arrangements position the child in and in relation with the world. What kind of subject positions are, in other words, made available in and through particular arrangements and what kind of opportunities does this create for children and young people to 'work' on their existence as a grown-up, non-egological subject: in the world but not in the centre of the world.

key words: philosophical work with children; egological and non-egologial subject; grown-up-ness

\section{tocando a alma? explorando uma visão alternativa para o trabalho filosófica com crianças e jovens}

resumo

O trabalho filosófico com crianças - que considero uma frase abrangente e ligeiramente mais descritiva para cobrir uma série de atividades educacionais com crianças e jovens em que a filosofia desempenha um papel - ocupa um lugar bastante singular no currículo contemporâneo e na escola moderna em muitos países ao redor do mundo. Isso não apenas proporciona um sopro de ar fresco, mas também atua como um lembrete de que há muito mais na educação do que onde os políticos e gestores continuam querendo empurrá-la, e também que a educação deveria ser bem mais do que isso. Mas a pergunta que gostaria de colocar aqui é se isto é suficiente. Neste artigo, compartilharei algumas das minhas observações sobre minhas experiências com o trabalho filosófico com crianças e jovens, não para julga-las. Talvez a melhor maneira de "ler" o meu argumento é vê-lo como a partilha de uma questão - uma questão relevante para todos os projetos educativos, programas, empreendimentos e práticas, e, portanto, também relevante para o trabalho filosófico com crianças e jovens. A questão que levanto é a forma como determinadas práticas, configurações e arranjos educacionais colocam a criança no mundo

\footnotetext{
${ }^{1}$ E-mail: gert.biesta@brunel.ac.uk
} 
touching the soul? exploring an alternative outlook for philosophical work with children and young people

e em relação com ele. Que tipo de posições de sujeito, em outras palavras, estão disponíveis em e através de arranjos particulares e que tipo de oportunidades isso cria para que crianças e jovens "trabalhem" em sua existência como sujeitos crescidos e não egológicos: no mundo, mas não no centro do mundo.

palavras-chave: trabalho filosófico com crianças; sujeito egológico e não egológico; crescimento

\section{¿tocando el alma? explorar una visión alternativa para el trabajo filosófico con niños y jóvenes}

resumen

El trabajo filosófico con los niños -que considero como una frase abarcadora y ligeramente más descriptiva para cubrir una gama de actividades educativas con niños y jóvenes en los que la filosofía juega un papel- ocupa un lugar singular en el currículo contemporáneo y en la escuela moderna en muchos países del mundo. No sólo proporciona un soplo de aire fresco, sino que también sirve como un recordatorio de que hay más en la educación que el lugar los políticos y gestores desean impulsarla, y también que la educación debería ser más que esto. Pero la pregunta que quiero hacer es si eso es suficiente. En este trabajo, compartiré algunas de mis observaciones sobre mis experiencias con el trabajo filosófico con niños y jóvenes, no para emitir un juicio sobre esto. Tal vez la mejor manera de "leer" mi argumento es verlo como el compartir una pregunta - una cuestión relevante para todos los proyectos educativos, programas, esfuerzos y prácticas, y por lo tanto también relevante para el trabajo filosófico con niños y jóvenes. La pregunta que planteo es cómo las prácticas educativas, los ajustes y los arreglos particulares sitúan al niño en y en relación con el mundo. En otras palabras, ¿qué tipo de posiciones están disponibles en y por medio de arreglos particulares y qué oportunidades crean para que los niños y jóvenes "trabajen" en su existencia como sujetos crecidos y no egológico: en el mundo, pero no en el centro del mundo.

palabras clave: trabajo filosófico con niños; sujeto egológico y no egológico; crecimiento. 
touching the soul? exploring an alternative outlook for philosophical work with children and young people

\section{preamble}

One of the main questions I explore in this paper is what particular educational 'arrangements,' to use a broad term, 'do' to the children and young people they seek to address. More specifically I ask what kind of existential possibilities (BIESTA, 2015a) or, in more technical language, what kind of subject positions (FOUCAULT, 1983) such arrangements offer. This admittedly existential question is, however, not just at stake in educational settings and contexts, but can be asked with regard to each situation we find ourselves in. It can therefore also be asked in relation to the very reading of this paper and, since this paper is based on a presentation, it can also be asked about the presentation itself. The question with which I wish to preface this paper, therefore, is where what is being said actually 'arrives' with us. Where, in other words, is what is being said received? This is all I wish to say at this point, but I hope that the reader will carry their response to this question with them throughout their reading of the paper.

\section{the significance of philosophical work with children}

Philosophical work with children - which I take as an encompassing and slightly more descriptive phrase to cover a range of educational activities with children and young people in which philosophy plays a role - occupies a rather unique place in the contemporary curriculum and the modern school in many countries around the world. This is without doubt the result of the efforts of many who have struggled and are continuing to struggle to make philosophy into a legitimate part of the educational endeavour. Much has already been achieved and such these achievements should be welcomed and celebrated. After all, in an age in which educational policies and practices tend to focus on filling children and young people with answers, philosophy - also in its more active form of philosophising, of doing philosophy - has carved out a space for a different gesture, that is, for asking questions, for asking better questions and for asking 
touching the soul? exploring an alternative outlook for philosophical work with children and young people

questions better. This contribution should not be underestimated, particularly not in an age of educational instrumentalism and, more specifically, an age of measurement (BIESTA, 2010), in which many education systems are geared towards the production of the test scores the Global Education Measurement Industry (BIESTA, 2015b) apparently 'needs' in order to judge which education systems perform better and which perform best. Philosophical work with children not just provides a breath of fresh air, but also acts as a reminder that there is more to education than where policy makers and politicians keep wanting to push it, and also that education ought to be more than this.

This, so I wish to emphasise, is all good. But the question I wish to ask is whether it is enough. Looking at philosophical work with children and young people as a relative outsider, I have two concerns. One is the risk of instrumentalisation, that is, that philosophical work with children is understood as critical thinking, and that critical thinking is seen as nothing but a useful skill for navigating the uncertain world of - or as some would argue: created by global capitalism. If philosophical work with children would end up in the list of 21st century skills it would, in my view, have lost its critical but also its philosophical 'edge.' I am not sure what the best word for the other concern I have is - perhaps we might call it the risk of mentalisation - but what I am hinting at is that, despite the explicit ambition to make thinking not just critical but also creative, caring and collaborative, it nonetheless remains thinking and nonetheless stays 'in the head,' so to speak.

My concern is that philosophical work with children and young people feeds their thinking but does not really reach their heart or touch their soul. One could of course argue that education has nothing to do there, that this is the dangerous terrain education should stay away from (but see, for example, RUITENBERG, 2010) and that it should rather focus on helping students to keep a clear head. This is the argument for thinking and, more specifically, for thinking well. There is, of course, nothing wrong with thinking well - although a key question is what the criterion for well-ness might be - but the point I wish to raise 
here is whether there may be limits to thinking and limits to what thinking may achieve.

\section{are there limits to thinking?}

One of the reasons why I am a great fan of gardening in schools is not because it provides opportunities for experiential forms of physics or chemistry lessons, but because the remarkable thing about plants is that you can think about them as long and as hard as you wish but that, as far as we know it, this won't alter the speed at which they grow. In gardening, we thus meet a reality that, in a sense, is immune for our thinking; a reality that cannot be touched by are thinking but asks for a different attitude - patience, for example, or endurance. There is a similar reason why I am a fan of animals in schools, again because their existence is not susceptible to our thinking but rather asks something from us - attention, for example, and care. It is also for this reason that I am a fan of schools, not as places for learning (see below), but as places of encounter, where people come together (see also MASSCHELEIN \& SIMONS, 2013).

Let's say, then, that there is nothing 'wrong' with thinking, as long as we do not forget paying attention to the difference between our thoughts about the world and, if I dare using this expression, the world itself. Otherwise we may end up living in an idea about the world rather than in the world itself (on this see also BIESTA, 2017a). I am of course aware of the philosophical complexities of what I am suggesting here, but what I am concerned about are the existential implications of this. I am concerned, for example, about the fact of young people but not only young people - who live in an idea of their body rather than their body and thus end up wanting to adjust their body to their idea about their body (and there is of course a huge industry available to sort this out for them). Similarly, there is the danger of conflating our idea of the world with the real world, which may lead to the desire for wanting to adjust the world to our idea of it - which could be taken as a definition of technology, but also as a definition of war and even of terrorism (see also HEIDEGGER, 1977). 
touching the soul? exploring an alternative outlook for philosophical work with children and young people

\section{the educational question}

It is somewhere here - and I will provide more detail below - that I would like to locate the educational question which, so I wish to suggest, is not the question of learning (on this see BIESTA, 2004; BIESTA, 2013) but the question of coming to exist in and with the world as subject. Existing as subject, as Philippe Meirieu (2007, p.96) has put it so very well, is about existing in the world - and not, so I would like to add: in an idea about the world - without putting oneself in the centre of the world. Existing as subject means to be in dialogue with the world, natural and social, if we think of dialogue not as conversation but as an existential 'form,' a way of existing-with. The task of the educator in relation to this, as I have put it elsewhere (BIESTA, 2017b, chapter 1), is to arouse the desire in another human being for wanting to exist in the world as subject. Such an understanding of the educational question and the educational task hints at an approach to education that is neither child-centred nor curriculum-centred but might best be characterised as world-centred (see also BÖHM, 2017; and BÖHM, 1997), as it is focused on the challenge for the child and young person - and in a sense for every human being - to exist in and with the world.

\section{encountering philosophical work with children}

If there is an ambition in this paper - I tend to be careful with ambitions - it is perhaps to bring philosophical work with children more closely to the educational question, or at least to provide a framework for exploring what it might mean to engage more explicitly with the educational question in philosophical work with children and young people. Before I say more about this, it may be helpful to mention that my encounters with philosophical work with children, which have taken place in a range of different countries and languages, have not been entirely 'happy,' if that is the right word. I have mainly seen practices that were strongly conceptual and verbal, emphasising arguments and argumentation and often working towards logical conclusion. I have seen little that was explicitly experiential, that is, trying to make connections with children's experiences (not their ideas or their thinking), and have also seen little that 
provided opportunities for engagement beyond discussion and argumentation. It thus worked quite well for children who can handle words and arguments, concepts and conversations, but far less so for children who are not 'there.'

This also gave me the impression that only a particular 'slice' of the philosophical tradition was being represented, more on the analytical-logical side of the philosophical spectrum, and less on the phenomenological and more speculative end. Now I may have been unfortunate in the examples I have encountered - though the pattern has been fairly consistent - and am of course willing to be corrected. Yet what concerns me - and this is the question I will pursue - is how these particular 'stagings' of the encounter between children and philosophy, positions them in and in relation to the world. What kind 'I,' to put it differently, emerges from these encounters and where and how does this ' $\mathrm{I}$ ' emerge? What kind of subject positions are created and encouraged and what kind of subject positions are, by implication discouraged or absent? My intuition here is that, at least in the examples I have witnessed, the focus was more on the ' $\mathrm{I}$ ' who raises questions than on the ' $I$ ' who, to use an expression from Levinas (1981, p.111), is in question. To identify what is at stake here, I now need to zoom 'out' to the more general question as to what is happening with the ' $\mathrm{I}$ ' of the child and student in contemporary education in order, towards the end of the paper, bring this back to philosophical work with children.

\section{the learnification of contemporary education}

If there is one trend that has taken hold of education over the past 15 to 20 years it is the turn towards learners and their learning. As I have documented in detail elsewhere (see particularly BIESTA, 2006a; 2010), the shift towards learners and their learning is first and foremost visible in the rise of the language of learning in education. This rise is visible in a number of discursive shifts, such as the tendency to refer to pupils, students, children and adults as 'learners,' to refer to teaching as the facilitation of learning, to talk about schools as learning environments or places for learning, or to rename the field of adult education into that of lifelong learning. 
touching the soul? exploring an alternative outlook for philosophical work with children and young people

There are definitely empowering dimensions to these shifts, particularly to the extent to which they are a response to authoritarian forms of education that were only interested in the input-side of education or in teaching as an act of control. But there are also darker sides to these shifts, particularly in the way in which they are entangled with neo-liberal policies that seek to shift responsibilities away from the collective towards individuals, something that is particularly visible in the transformation of the right to adult education into the duty to keep learning throughout one's life, often in order to remain employable in an evershifting job-market (see BIESTA, 2006b).

At a discursive level, one of the main problems with the rise of the "new language of learning' is that it has taken attention away from a number of key educational questions and concerns. After all, the point of education - that is, when we bring people, resources and time together in order to bring about education - is not that children or students learn, but that, to put it briefly, they learn something, that they learn it for a reason and that they learn it from someone. The language of learning is a language of process but says little about the content and direction of such processes. Education, however, always raises questions about content, about purpose and about relationships and one could argue, as I have done, that the language of learning has taken attention away from these crucial educational concerns.

This is not to say, of course, that under the language of learning content has disappeared, direction is absent or relationships no longer play a role. It rather is meant to highlight that the language of learning runs the risk of hiding the decision-making going on about content, purpose and relationships. This, I think, is one of the reasons why the cult(ure) of measurement and of measurable learning outcomes appears to have succeeded in re-defining what education is supposed to be for, with teachers becoming servants of the system rather than being key agents in the educational endeavour (see also PRIESTLEY, BIESTA \& ROBINSON, 2015). In this regard the rise of the language of learning is a classic 
example of ideology, in that it both expresses and hides the power relations that are at work (see EAGLETON, 2007).

The rise of the language of learning and the wider 'learnification' of educational discourse and practice has not only changed the educational conversation, but has also affected identities, relationships and subject positions. It has put learners and their learning at the centre of educational attention and has moved teachers from being the 'sage on the stage' to being the 'guide at the side' and, according to some, being the 'peer at the rear,' a learner amongst other learners in what, in fashionable parlance, is often referred to as a 'learning community' or 'community of learners.' Let me emphasise once more that in my view these expressions are ideological in that they hide more than that they make visible. They hide, for example, the power differential that is always at stake in educational relationships but also, and in my view more importantly, they hide the differing responsibilities of teachers and students in such relationships.

What I'm interested in for the line I am pursuing in this paper is the question how the 'logic' of learning positions students in the world. I'm interested, in other words, in the particular subject position(s) created by the logic of learning or, in more precise language, what the logic of learning and of being a learner 'does' to the 'I' of the student.

\section{theorising learning: the paradigm of intelligent adaptation}

The question of the definition of learning is at the same time simple and complicated. At the simple end of the spectrum a definition of learning as any more or less durable change that is not the result of maturation gives a good indication of what learning is about. It indicates that learning has something to do with what we acquire from interactions with environments, to put it in general terms. Wikipedia is helpful here as well, as the opening sentence of its item on learning provides a slightly more detailed description of this general definition when it defines learning as "the act of acquiring new or modifying and reinforcing existing knowledge, behaviors, skills, values, or preferences which may lead to a potential change in synthesizing information, depth of the knowledge, attitude or 
touching the soul? exploring an alternative outlook for philosophical work with children and young people

behavior relative to the type and range of experience" (accessed on 25 July 2017). Interestingly, at least for the line I wish to pursue here, is the sentence immediately following this one, which states that " $(\mathrm{t})$ he ability to learn is possessed by humans, animals, plants and some machines" (Wikipedia, accessed on 25 July 2017).

At a behavioural level, learning is about the ways in which organisms or systems adjust to changing environing conditions and about the ways in which organisms or systems change as a result of this. At a behavioural level such changes result in changed patterns of action which John Dewey, who has an extensive theory of how living organisms learn, refers to as 'habits' which he defines as predispositions to act (for a reconstruction and discussion see BIESTA \& BURBULES, 2004). Whereas Dewey focuses on living organisms - and credits language as the key factor in transforming 'blind' trial and error into intelligent action - the underlying understanding of learning applies to both living organisms and non-living systems.

A good (and also telling; see below) example of such an intelligent adaptive system is the robot vacuum cleaner. Robot vacuum cleaners are able to move autonomously in the environment they are being placed in - that is, as long as their batteries are sufficiently charged - and while in a first run they may bump into objects in the room they are cleaning, over time they will move around such objects and become more effective at the task of cleaning the floor. The robot vacuum cleaner is therefore not just a good image of an adaptive system, but also of an intelligent system, that is, a system that can learn as a result of its 'encounter' with (objects in) an environment.

The image of the robot vacuum cleaner actually provides a rather accurate image of learning-focused education, where teachers are not there to impart knowledge to students but are seen as designers of learning environments that set particular tasks for learners, but where it is for learners, through interaction with learning environments, to reconstruct their patterns of action and thought. Just as robot vacuum cleaners become more effective at their task when placed in a range 
of differing environments, learners acquire habits and skills that will allow them to adjust more effectively to new environments.

The robot vacuum cleaner therefore not only provides an accurate image of the logic of learners and their learning environments, but also fits well with trends in contemporary education where it is argued that rather than providing students with 'old' knowledge, they should be equipped with the skills to adapt and adjust to new and as yet unknown environments. Interestingly, the robot vacuum cleaner also fits with the critique of teaching as transmission, a critique that can already be found in the work of Dewey (1966, p.19), who argued that "we never educate directly, but indirectly by means of the environment" - that is by putting adaptive systems in new and different contexts.

\section{what is missing?}

The idea of intelligent adaptive systems such as robot vacuum cleaners not only provides us wit a rather accurate account of the basic dynamics of learning. It also provides us with a remarkable accurate picture of what I have referred to as learning-focused education - and perhaps we can also call this learner-focused education. In addition, although I have only hinted at this, the idea of learning as intelligent adaptation also fits well with many varieties of educational constructivism, and again we might say that the robot vacuum cleaner provides us with a remarkably accurate picture of the constructivist classroom. Although the fit appears to be 'perfect,' I wish to argue that there are two things missing in the picture and that these begin to indicate some of the limits of this particular depiction of learning and its educational application.

The first thing that is missing is that intelligent adaptive systems, be they organic or anorganic, are capable of adapting intelligently to changing environing conditions (and in the process acquire dispositions, skills and knowledge), but the question they cannot issue out of themselves is the question whether the environment they find themselves is worth adapting to. Where the idea of learning as intelligent adaptation breaks down, or at least reaches an important limit, is in the fact that intelligent adaptive systems are entirely functional systems, 
touching the soul? exploring an alternative outlook for philosophical work with children and young people

aimed at survival but not, so we might say, capable of meaningful life. They are able to execute an algorithm but are not able to generate a criterion, to put it briefly.

The second thing that is missing is that intelligent adaptive systems are unable to receive. They can, in other words, not be spoken to, they cannot be addressed, which also means that they cannot be taught. The only thing they can do is (to try) to adjust to what they encounter. This means that in the 'paradigm' of intelligent adaptive systems the world, natural and social, can only appear as an obstacle, as something that gets in the way and requires adjustment from the system or organism. In this paradigm, therefore, another human being can only appear as an obstacle to adjust to, and not as someone I am in communication with, someone who speaks to me, who addresses me, who touches me, who asks for me or, with a phrase from Levinas (1989 p.195), who calls "upon the unique within me."

There are two ways to go with regard to these observations. One is to argue that the paradigm of intelligent adaptation is true and that the elements that are missing are at most epiphenomena, but not dimensions that really exist. The other option is to argue that there is something fundamentally wrong with the paradigm because it misses out essential dimensions of what it means to exist as human being in and with the world, particularly that such existence cannot be reduced to the question of survival and that the experience of being spoken to, of being addressed, of receiving the words of another human being, is a real experience.

I wish to follow the second line, which means that I am not only making a case for the idea that meaningful human life cannot be reduced to matters of survival, but that I am also arguing that the speech of the other is a real experience and something that we can receive and that can 'arrive' in us which, by implication, is also an argument for saying that teaching is possible and real and not just a matter of arranging environments. I am willing to concede that learning can be a richer concept than what is captured in the idea of intelligent adaptation although I wish to emphasise how pervasive this idea has become in 
contemporary learning theory - but do want to argue that to the extent to which our understanding of learning relies on the 'paradigm' of intelligent adaptation, it is significantly lacking, both humanely and educationally.

\section{considering two subject positions}

When we come to education through the logic of learning - though we could also say: when we come to life through the logic of learning - we find a learner at the centre, as the ' $\mathrm{I}$ ' who asks questions and makes sense or, in more philosophical language, who is the origin of signification. The subject position at stake here is one where the subject exists before the world, both temporally and spatially, and where the world, natural and social, appears as an object for the subject's acts of signification. Central questions here are 'How can I understand this?' and 'How can I make sense of it?' The subject position at stake in the logic of learning, in other words, is that of comprehension of literally grasping the world in its totality. This is the subject position that is being made available in learningfocused education. But it is not the only conceivable subject position.

There is a different question, a different gesture, so we might say, and a different subject position, which centres around the question 'What is this asking from me?' - a question that refers to what comes to the subject, so to speak. This is the way in which Emmanuel Levinas approaches the question of subject-ness, where the subject is not seen as the origin of signification but is rather "awakened by the other" (LEVINAS, 1989, p. 209; emphasis added). Levinas refers to this 'event' of awakening as ethics, but ethics is not what (pre-ethical) subjects engage with or decide to. Ethics rather is the event of awakening, because it is when we encounter (a) responsibility, when we are called upon by the other, that our subject-ness becomes an 'issue,' so to speak, that our subject-ness matters. Zygmunt Bauman (1993, p.13) captures this idea wonderfully when he summarises it with the phrase that "responsibility is the first reality of the self."

If the first subject position can be characterised as the subject position of learning, the second subject position can be called the subject position of teaching or, to be more precise, the subject position of being taught, of encountering (a) 
touching the soul? exploring an alternative outlook for philosophical work with children and young people

teaching, that is, an address that comes to us from the outside (and radically from the outside, so I wish to add, not as something constructed by us). The address, the other who speaks to me and in doing so 'singles me out,' as it is said in English, puts my subject-ness at stake. Levinas is keen to emphasise that the heteronomous origin of my subject-ness is not a total submission. He argues that it should be understood as a "heteronomy which does not involve servitude, a receptive ear which still retains its reason, an obedience which does not alienate the person listening" (LEVINAS, 1989, p.207). The address, in other words, calls the subject into the world, and it is at this point that I wish to return to what, above, I have identified as the educational question.

\section{existing as subject, in the world, without being in the centre of the world}

I have argued above that education cannot and should not be reduced to learning and have, in relation to this, tried to show what might be missing if we limit understanding of education and, for that matter, our understanding of what it means to exist humanely in the world, to the question of learning. I have, instead, suggested a broader and more existential 'scope' for education, by arguing that the educational question is about coming to exist in and with the world as subject.

Existing as subject, as the phrase tries to indicate, is an existential matter, and should not be conflated with the question of identity. I see identity primarily as a concern with the question who we are in terms of how we might identify ourselves and what we might identify with. The question of subject-ness, on the other hand, is a matter of existing. It is, although the term sounds slightly too static, about our position as subject, and I have already tried to indicate that the subject position of learning as intelligent adaptation is very different from the Levinasian subject position where our subject-ness is being called for from the outside.

Here our subject-ness is being put 'at stake' in situations where we encounter a responsibility or, to be more precise, where I encounter a responsibility, and where it is up to me - and no one else can do that for me - to 
take responsibility for this responsibility or to walk away from it. And in both 'options' our freedom, our possibility to say yes or not, to stay or walk away, to go with the flow or offer resistance, comes into play. The call to subject-ness is therefore not an act of suppression - it is not a call to give up our freedom - but is a kind of 'double move' where, by being called into the world we are also called to come into a relationship with our freedom. It is less the case that in this double move our subject-ness emerges, as such a description would run the risk of turning subject-ness into a thing, and more accurate to say that in this double move our existing as subject is 'at stake,' matters, becomes relevant and hence becomes real.

Existing as subject is therefore not something that occurs in a vacuum; it necessarily occurs in the world, natural and social. The world, however, should not be understood as a context or backdrop, but is what we encounter when we take initiatives, when we initiate something. The world first and foremost appears in the way in which it offers resistance - quite literally - to our initiatives. The experience of resistance, of something or someone offering a counter-force, so to speak, is a crucial experience because it reveals that the world (once more: natural and social) is not a construction but exists outside of us and independently from us. The experience of resistance is in this regard an encounter with what, after Freud, we might call the reality principle. Just as it reveals an independent world existing outside of us, the experience of resistance reveals at the very same time our initiatives and, more specifically, what we desire to initiate (see also BIESTA, 2017a).

The encounter with resistance is a frustrating experience because we meet something that, in a sense, gets in the way of our initiatives (although it is also the very condition under which our initiatives can enter the world, can become real). One possible response to this frustration is to start pushing harder, putting more effort and energy and force in our initiatives in order to overcome the resistance we meet. This is important for things to happen and become real, but one can imagine that if one pushes too hard there will come a point where our initiatives 
touching the soul? exploring an alternative outlook for philosophical work with children and young people

will destroy the world in which they try to enter. At one extreme, therefore, we encounter the risk of world-destruction. But the same sense of frustration that follows form meeting resistance can also be that we give up, that we take back our initiatives and that we take back and withdraw ourselves. The extreme we encounter here is the total withdrawal from the very world in which we seek to exist - an extreme which we may want to refer to as self-destruction.

Being in the world, existing in the world as subject, thus means to stay in the difficult and precarious 'middle ground' between the two extremes of worlddestruction and self-destruction. Staying in this middle ground is an ongoing - we might say lifelong - challenge, a question that arises each time we initiate, each time we take initiative, each time we seek to bring something into the world. Staying in the middle ground can be understood, as I have indicated above, as a matter of dialogue - being in dialogue with - as long as we do not think dialogue as verbal conversation but as an existential form. Finally, if it is the case that the education question is the question of how to (come to) exist as subject, then we might say that the middle ground between world-destruction and self-destruction is the space and place of education.

\section{existing in a grown-up way: the desired and the desirable}

Elsewhere (BIESTA, 2017b, chapter 1) I have referred to the 'condition' of existing as subject as a grown-up way of existing. Although grown-up-ness is a part of the vocabulary of education, it has become tainted by developmental interpretations that see grown-up-ness as the outcome of an educational or developmental trajectory, and hence as a kind of achievement which, once achieved, remains with the one who can now be seen as 'having grown-up.' I would like to suggest a different, existential way of understanding the idea of grown-up-ness, precisely not as outcome of development but as a way of trying to exist in and with the world, a way of existing in dialogue with what and who is other.

In more technical terms, existing as subject in a grown-up means to try to exist in a non-egological way, that is, in a way not dominated by the logic of the 
ego. If the egological way of existing is one where one pursues one's own desires, whatever it may take, the non-egological way always asks the question whether what one desires, what one encounters in oneself as a desire, is what one should desire. The non-egological way is, in other words, the way where one tries to put one's own desires in perspective.

Asking the question whether what one desires is what one should be desiring, is not just a question one needs to ask in relation to one's own life, but is also and crucially a question one should ask in relation to the life we live with others on a planet that has limited capacity for fulfilling all the desires project onto it. Carrying the question of the desired and the desirable with oneself throughout one's life, is not meant to suppress desires but to question, select and transform them, so that they can support grown-up ways of trying to be in and with the world. Here Spivak's (2004, p.526) definition of education as the "uncoercive rearrangement of desires" remains perceptive and helpful.

\section{the educational work, beyond (facilitation of) learning}

It will hopefully be obvious that no one can be forced to exist as subject, in a grown-up, non-egological way, because the whole point of existing as subject is that one comes into a relationship with one's own freedom. This is why education, if it is interested in the subject-ness of children and young people, cannot be understood in terms of production or cultivation, because the subject is not a thing but rather subject-ness is a way of existing, of bringing one's freedom, including the freedom to initiate, in relation with the world. This is why I tend to refer to the educational work as arousing the desire in another human being for wanting to exist in and with the world as subject, that is, in a grown-up way. This suggests a number of things for the way in which education is enacted.

The first thing it highlights is that education, if it is aimed at the subjectness of children and young people, is fundamentally of an interruptive nature. Education is an interruption of desires, an interruption of being-with-oneself, an interruption of identity, in all cases with the intention to call the child or student into non-egological existence in and with the world. This, so I wish to suggest, is 
touching the soul? exploring an alternative outlook for philosophical work with children and young people

the basic 'form' of education, although there are further questions to be asked about how this form can be and ought to be enacted. It is one thing to interrupt where children and young people are in order to turn them and their attention towards the world and the possibility for existing as subject in and with the world. It is still another to make space, create forms and give time for children and young people to meet the world, to encounter resistance, to meet their own desires in relation to what and who is other, and to try out what it might mean to come into dialogue with the world.

Education, when viewed along these lines, is therefore not just characterised by its interruptive nature, but also by the quality of suspension: of slowing down, of giving time, of providing forms where children and young people can meet themselves and the world, and engage with the question of the desired and the desirable, that is, of practising grown-up, non-egological ways of being-with. Next to interruption and suspension, education, if it is oriented towards the subject-ness of children and young people, needs to provide sustenance to help them to stay in the difficult middle ground so that their desire for wanting to stay there can grow. Sustenance is particularly needed because in the difficult middle ground we often what, at first sight, does not look attractive or motivating yet in the longer term may turn out to be quite significant.

Arousing the desire in another human being for wanting to exist in the world in a grown-up way, interrupting egological ways of being, suspending the focus on the immediate so that there is time to encounter the world, encountering one's desires with regard to the world, and work on the rearrangement of these desires, and providing sustenance so that children and young people not only might manage to stay in the difficult middle ground but develop an appetite for that particular location, is not the common vocabulary we find in contemporary education. But it is an attempt to highlight what the work of the educator entails if it is interested in the subject-ness, the existing-as-subject, of children and young people. 
In this paper, I have tried to develop what I would characterise as an indirect argument. I have shared some of my observations about my experiences with philosophical work with children and young people, but have not passed any judgement on this - also because I know that there is always more than meets the eye. I also have no desire to tell those who are involved in philosophical work with children and young people what they should and should not being doing. Nonetheless I am always interested in exploring whether things can be done or seen differently, at least so that we know better what we are doing and what we are not doing.

Perhaps the best way to 'read' my argument is to see it as the sharing of a question - a question relevant for all educational projects, programmes, endeavours and practices, and hence also relevant for philosophical work with children and young people. The question I have raised is how particular educational practices, settings and arrangements position the child in and in relation with the world. What kind of subject positions are, in other words, made available in and through particular arrangements and what kind of opportunities does this create for children and young people to 'work' on their existence as a grown-up, non-egological subject: in the world but not in the centre of the world.

I have raised some questions about thinking, particularly indicating those domains of life and living that cannot really be affected by thinking - the growth of a plant, the existence of an animal, and the existence of other human beings and rather seem to ask something from us. I have also raised questions about learning as a mode of being, so to speak, highlighting that the paradigm of learning as intelligent adaptation lacks (at least) two things that, in my view, are essential dimensions of our existence as human beings.

The first thing that is missing is the criterion. The question here is where in the paradigm of learning as intelligent adaptation there is a place for the question whether the environment we find ourselves in is an environment worth adapting to. I wish to emphasise that I am not denying that as human beings we are able to raise such questions. What $\mathrm{I}$ am arguing is that the paradigm of learning as 
touching the soul? exploring an alternative outlook for philosophical work with children and young people

intelligent adaptation cannot account for this and that this is a serious shortcoming of the paradigm.

The second thing that is missing in this paradigm, is the very possibility of teaching or, to be more precise, the very possibility of being taught, of receiving a teaching, of being addressed, of being spoken to. The paradigm of learning as intelligent adaptation, and the many versions of constructivism that are part of this paradigm, is unable to account for this. And again, I wish to emphasise, that for me - but here lies the significance of the question with which I opened this paper - the experience of receiving the speech of the other, of being addressed, of being touched, is a real experience, which therefore shows an important limitation of the paradigm of learning as intelligent adaptation.

From my experience, philosophical work with children is particularly strong in helping children and young people to ask questions - about the world, about their own role and position in it - and thus can contribute to understanding of and learning about the world. The subject position that is made available in this way, is that of the I who asks questions, who makes sense, who seeks to understand. This subject, as I have tried to indicate, exists before the world, both spatially and temporally, which means that the world, natural and social, appears for this subject as an object of learning, understanding, sense-making, even, of course, if such sense-making is limited and understanding never reaches an end.

What I have tried to suggest is that there is at least another subject position possible, not as the subject who asks questions but as the subject who is being put in question and through this is being called into the world. Here the subject does not exist before the world and the world is not the object of the subjects desire to learn and understand. What appears as world, so to speak, is rather what address the self, calls the self to exist as subject - in the world but not in the centre of the world.

If the educational work with regard to the first subject position is about adding questions, sharpening up questions, helping children and young people to ask different, more and better questions so as to enhance their learning and 
understanding and their comprehensive 'capacities,' the educational work with regard to the second subject position is of a rather different quality: it is characterised by interruption, it works through suspension and it requires sustenance. This is partly in order to provide children and young people with opportunities to find out what it might mean to come into dialogue with the world, to try to exist as subject. But the educational work is also there in order to try to arouse the desire in children and young people for wanting to exist in and with the world in this way.

This, so I wish to conclude, is not a matter of providing them with knowledge, skills and understanding - an approach that has its place in the first educational 'gesture' of empowering children and young people to become better at questioning. Rather than building up their power and trying to empower them, the second educational 'gesture' rather seeks to arouse their desire for wanting to exist in the world as subject, in the difficult middle ground. This is much more a matter of disarmament (see MASSCHELEIN, 1997), so that their heart can be reached and their soul can be touched.

Whether the second educational gesture is seen as a relevant dimension of and direction for education - I hesitate to call it an alternative paradigm - is a judgement I leave to the reader. From my perspective, I think that the existential approach to education I have tried to outline in this paper, provides an educational orientation that may well expand the reach and significance of philosophical work with children and young people beyond where much of this work currently seems to be located.

\section{references}

BAUMAN, Z. Postmodern ethics. Oxford: Wiley-Blackwell, 1993.

BIESTA, G.J.J. Against learning. Reclaiming a language for education in an age of learning. Nordisk Pedagogik 23, 70-82, 2004.

BIESTA, G.J.J. Beyond learning: Democratic education for a human future. Boulder, Co: Paradigm Publishers, 2006a.

BIESTA, G.J.J. What's the point of lifelong learning if lifelong learning has no point? On the democratic deficit of policies for lifelong learning. European Educational Research Journal 5(3-4), 169-180, 2006b. 
touching the soul? exploring an alternative outlook for philosophical work with children and young people

BIESTA, G.J.J. (2010). Good education in an age of measurement: Ethics, politics, democracy. Boulder, Co: Paradigm Publishers, 2010.

BIESTA, G.J.J. Interrupting the politics of learning. Power and Education 5(1), 4-15, 2013. BIESTA, G.J.J. Freeing teaching from learning: Opening up existential possibilities in educational relationships. Studies in Philosophy and Education 34(3), 229-243, 2015a.

BIESTA, G.J.J. Resisting the Seduction of the Global Education Measurement Industry: Notes on the Social Psychology of PISA. Ethics and education 10(3), 348-360, 2015b.

BIESTA, G.J.J. Letting art teach: Art education after Joseph Beuys. Arnhem: ArtEZ Press, 2017a.

BIESTA, G.J.J. The rediscovery of teaching. London/New York: Routledge, 2017b.

BIESTA, G.J.J. \& BURBULES, N. Pragmatism and educational research. Lanham, MD:

Rowman and Littlefield, 2003.

BÖHM, W. Entwürfe zu einer Pädagogik der Person. Gesammelte Aufsätze. Bad Heilbrun: Verlag Julius Klinkhardt, 1997a.

BÖHM, W. Vom Subjekt zur Person. In: Die pädagogische Placebo-Effekt. Zur Wirksamkeit der Erziehung (pp. 155-168). Paderborn: Ferdinand Schöningh, 2017.

DERRIDA, J. "“Honoris Causa: 'This is also very funny"”". Points . .: Interviews, 1974-1994 (1st ed.) (pp. 409-413). New York: Stanford University Press, 1995.

DEWEY, J. Democracy and education. New York: Free Press, 1966[1916].

EAGLETON, T. Ideology: An introduction. New and updated edition. London/New York: Verso, 2007.

FOUCAULT, M. The subject and power. In H. Dreyfus and P. Rabinow (Eds), Michel Foucault: Beyond structuralism and hermeneutics (pp. 208-226). Chicago, IL: University of Chicago Press, 1983.

HEIDEGGER, M. The question concerning technology, and other essays. New York: Harper \& Row, 1977[1953]

LEVINAS, E. Otherwise than being or beyond essence. The Hague: Martinus Nijhoff, 1981.

LEVINAS, E. Revelation in the Jewish tradition, in: S. Hand (ed), The Levinas reader (pp. 190-211). Oxford:, Blackwell, 1989.

MASSCHELEIN, J. In defence of education as problematisation: some preliminary notes on a strategy of disarmament. In: D. Wildemeersch, M. Finger \& T. Jansen (Eds), Adult education and social responsibility: Reconciling the irreconcilable? (pp.133-148). Frankfurt: Peter Lang, 1997.

MASSCHELEIN, J. \& SIMONS, M. In defence of the school: A public issue. University of Leuven, 2013.

MEIRIEU, P. Pédagogie: Le devoir de résister. Issy-les-Moulineaux : ESF éditeur, 2007. PRIESTLEY, M., BIESTA, G.J.J. \& Robinson, S. Teacher agency: An ecological approach. London: Bloomsbury, 2015.

RUITENBERG, C. Conflict, affect and the political: On disagreement as democratic capacity. In Factis Pax: Journal of Peace Education and Social Justice 4(1), 40-55, 2010. SMITH, B.et al. Open letter against Derrida receiving an honorary doctorate from Cambridge University. The Times [London], 9 May, 1992.

SPIVAK, G. C. Righting wrongs. The South Atlantic Quarterly, 103(2), 523-581, 2004. 
appendix: keynote at xviii icpic conference, madrid, june, 2017

Touching the soul?

Education, Philosophy and Children in an Age of Instrumentalism

Gert Biesta

Brunel University London

many thanks for the invitation

I speak, however, as an outsider outside of 'philosophical work with children'

outside of philosophy

as I consider myself to be an educationalist asking educational questions two questions before I start

$\downarrow$

Where does what is being said 'arrive'?

Where is what is being said 'received'? 
touching the soul? exploring an alternative outlook for philosophical work with children and young people

\section{philosophical work with children (pwc)}

occupies an important place in the contemporary curriculum

not filling children with answers but making space for asking questions,

asking better questions, asking questions better

$\downarrow$

particularly important in a competitive global educational culture that focuses on the production of measurable learning outcomes

a reminder that education ought to be more than this; but is it enough?

the risk that $\mathrm{PwC}$ becomes critical thinking, and that this becomes a useful skill for navigating the uncertain world of global capitalism

the risk that, despite the ambition to make thinking not just critical, but also caring, collaborative and creative, it stays 'in the head'

feeding thinking, but not reaching the heart and touching the soul

Should education go there or (rather) help students to keep a clear head? 


\section{are there limits to thinking?}

the importance of gardening in schools

meeting a reality that is 'immune' to our thinking but 'asks' something else - patience, for example

the importance of animals in schools

their existence is not dependent upon or susceptible to our thinking but 'asks' something else - attention, care

the importance of schools

where people come together

the difference between our thoughts about the world and the world itself

the risk that we end up living in an idea about the world rather than the world living in an idea about your body and wanting to adjust your body to this idea living in an idea about the world and wanting to adjust the world to this idea 
touching the soul? exploring an alternative outlook for philosophical work with children and young people

here we find an important educational question and perhaps even the educational question

education is not about learning,

but about coming to exist in and with the world as subject

"The student-subject is able to exist in the world, without putting itself in the centre of the world."

Philippe Meirieu

What is the educational task? see The Rediscovery of Teaching

"arousing the desire in another human being for wanting to exist in the world in a grownup way"

not child-centred, not curriculum-centred also not competence-centred, or skills-centred but world-centred 


\section{my encounters with philosophy for children}

strongly conceptual and verbal - far less experiential emphasising arguments and argumentations working towards logical conclusions

and representing a particular 'slice' of the philosophical tradition analytical-logical more than phenomenological or speculative

this is fine for children who can 'handle' this but perhaps not for everyone

but the main question I have is

how this 'positions' children in and in relation to the world

What kind of ' $\mathrm{I}$ ' emerges from these practices?

What kind of 'subject positions' are created/encouraged?

perhaps more the I who raises questions, than the I who is in question

What is happening with the I in contemporary education? 
touching the soul? exploring an alternative outlook for philosophical work with children and young people

\section{the 'learnification' of education}

the rise of a new language of learning

pupils/students/children/adults $\rightarrow$ learners teaching $\rightarrow$ facilitating learning

schools $\rightarrow$ learning environments adult education $\rightarrow$ lifelong learning the rise of the learning sciences

What is the problem?

the point of education is not that children/students learn ...

... but that they learn something, that they learn this for a reason, and that they learn it from someone

education always raises questions about content, purpose and relationships the language of learning makes it far more difficult to keep this into view 


\section{the main shift}

putting learners and their learning in the centre

and moving the teacher from the sage on the stage to the guide at the side

$\downarrow$

What does that do to the I of the student?

\section{what does the 'logic' of learning look like}

the learning sciences: the study of intelligent adaptive systems see also many forms of constructivism

including pragmatism (Dewey): intelligent organisms

$$
\text { for example }
$$

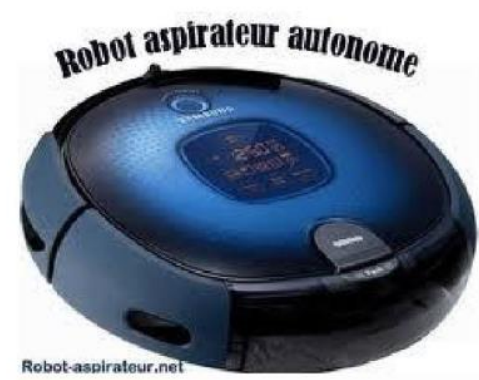

the learner

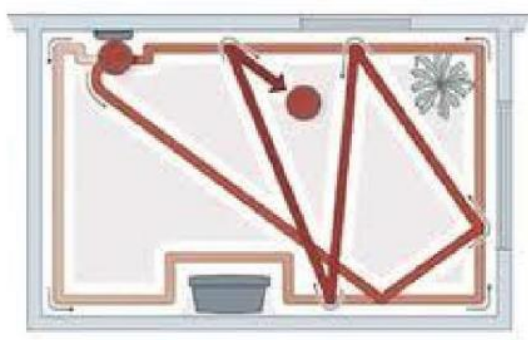

the learning environment

through being positioned in different learning environments learners can become more effective at adaptation to changing environing conditions

Dewey: "We can never teach directly, but only by means of the environment." see also "21st century skills"

Is this is an adequate conception of students in educational relationships? Is this an adequate view of human beings being-in-the-world? 
touching the soul? exploring an alternative outlook for philosophical work with children and young people

what is missing in this picture?

[1] the one question the intelligent adaptive system cannot issue, is whether the environment it is in is worth adapting to

it is, therefore, an entirely functional 'paradigm' aimed at survival, not life

(this is the in-built algorithm)

[2] the one event that cannot happen in this paradigm is teaching the system cannot receive a teaching,

cannot be spoken to, cannot be addressed

$\downarrow$

the world can only appear as an obstacle

the other human being can only appear as an obstacle something to adjust to

see Dewey and Mead on communication not someone I am in communication with

someone who speaks to me, who addresses me, who touches me someone who asks for me

who 'calls upon the unique in me' (Levinas) 


\section{considering two subject positions}

[1] the I who asks questions and makes sense the I who is the origin of signification

a subject who exists before the world: temporal and spatial the world as object of signification

'How can I understand this?' ‘How can I make sense of this?' comprehension: grasping in its totality

[2] a different question, a different gesture, and a different subject position

'What is this asking from me?'

ethics (Levinas): where the self is 'awakened by the other' 'responsibility as the first reality of the self' (Bauman)

"It is in the ethical event that the Ego gains its significance."

the address of the other singles me out - puts my subject-ness at stake

"a heteronomy which does not involve servitude, a receptive ear which still retains its reason, an obedience which does not alienate the person listening"

freedom: "doing what nobody else can do in my place"

a subject who is being called into the world 
touching the soul? exploring an alternative outlook for philosophical work with children and young people

\section{once more: the educational question}

"arousing the desire in another human being for wanting to exist in the world in a grownup way"

as subject - in the world, but not in the centre of the world

in the world: where our initiatives encounter resistance

experiencing that the world is not a construction but exists outside of us encountering the reality principle (Freud)

three possible responses

pushing hard to overcome resistance - world-destruction

withdrawing from what resists - self-destruction

staying in the difficult middle ground between world-destruction and self-destruction

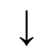

dialogue - not as conversation but as an existential form a lifelong challenge 


\section{in the world in a grown-up way}

as subject - in the world, but not in the centre of the world grown-up-ness

not the outcome of a developmental trajectory but a way of trying to be in the world

a non-ego-logical way of being

ego-logical: according to the logic of the ego pursuing one's desires

non-ego-logical: putting one's desires 'in perspective'

$\downarrow$

Is what I desire desirable?

for my own life, my life with others, on a vulnerable planet

not suppressing desires, but questioning and transforming desires education as the 'uncoercive rearrangement of desires' (Spivak) so that they can support grown-up ways of being in the world 
touching the soul? exploring an alternative outlook for philosophical work with children and young people

\title{
the educational work
}

\section{[1] INTERRUPTION}

interruption of desires, interruption of being with oneself, interruption of identity

$\downarrow$

world-centred education: (re)turning students to(wards) the world encountering the resistance of the natural and social world

\section{[2] SUSPENSION}

\author{
make space, give time and create forms
}

for meeting, considering and transforming our desires and for practicing grown-up-ness

[3] SUSTENANCE

providing support for staying in the difficult middle ground arousing the desire for staying there

showing that what is difficult in the short term, may be the better option in the longer term 


\section{concluding comments}

I have provided an indirect argument

I have no desire to tell people what they should and should not be doing, but am always interested in exploring whether things can be done differently so that we know better what we are doing (and what we are not doing)

for all those "interested in enquiry-based learning and critical thinking" and for all those who have an interest "in the development of high order, multidimensional or complex thinking" I have raised the question how this positions the child in and in relation to the world, natural and social

indicating limits of thinking

connecting education to the question of being in the world (in a grown up way) showing how the logic of learning puts children in the world

and what is missing from that picture

the question of the criterion

the possibility of teaching: being addressed 
touching the soul? exploring an alternative outlook for philosophical work with children and young people

\section{concluding comments}

showing two subject-positions

the I who asks questions, who makes sense the subject before the world

the I who is being put in question the subject being called into the world

being-in-the world: in the difficult middle ground in a grown-up way: from the desired to the desirable

and this suggests other forms of education, other educational work



disarmament

perhaps philosophical work with children has something offer there as well 